\title{
Pengaruh Kecemasan dan Motivasi Belajar dalam Pembelejaran Daring di Masa Pandemi Covid-19 Terhadap Hasil Belajar Sosiologi Siswa Kelas XII SMA Batik 1 Surakarta
}

\author{
${ }^{1}$ Ainun Rawie Eka Savitri, ${ }^{2}$ Abdul Rahman, ${ }^{3}$ Yosafat Hermawan \\ ${ }^{123}$ Pendidikan Sosiologi Antropologi, Universitas Sebelas Maret \\ Email: ainun.savitri@student.uns.ac.id, abdul.rahman@staff.uns.ac.id, \\ yosafathermawan@staff.uns.ac.id
}

\begin{tabular}{l}
\hline Article Info \\
\hline Article history: \\
Received 28 November 2021 \\
Publish 06 Januari 2022 \\
\\
\hline Keywords: \\
Anxiety, learning motivation, \\
soociology learning outcomes
\end{tabular}

\begin{tabular}{l}
\hline Info Artikel \\
\hline Article history: \\
Received 28 November 2021 \\
Publish 06 Januari 2022
\end{tabular}

Corresponding Author:

Ainun Rawie Eka Savitri

Pendidikan Sosiologi Antropologi, Universitas Sebelas Maret

Email:ainun.savitri@student.uns.ac.id

\begin{abstract}
This study aims to examine the relationship between anxiety, and learning motivation with sociology learning outcomes. This research method used in this study is a quantitative correlation with cross-sectional research design. The population of the research were the twelfth grade students of Batik 1 Surakarta High School. Sample of the research were 132 students who selected using sample random sampling technique. Data of the research were collected through documentation and questionnaire. Data analyzed using correlation productmoment analysis and multiple regression analysis.

Based on the Multiple Regression Test, the equation model $Y=50,992+0,073 X_{1}$ $+0,417 X_{2}$. Based on the Correlation Coefficient Test, the results show that: (1) there were not a correlation and not significant between anxiety with the sociology learning outcomes ( $\left.r_{\text {hitung }}=>r_{\text {tabel }}=0,168<0,1697 ; p>0,05\right) ;(2)$ there were a positive and significant correlation between learning motivation with the sociology learning outcomes ( $r_{\text {hitung }}=>r_{\text {tabel }}=0,485>0,1697 ; p<$ 0,05): (3) there were a significant correlation between anxiety and learning motivation with the sociology learning outcomes $\left(R_{x y}>R_{\text {tabel }}=0,509>0,1697\right.$; Sig F Change $=0,000<0,05)$.

\begin{tabular}{l} 
ABSTRAK \\
Penelitian ini bertujuan untuk menguji hubungan antara kecemasan dan motivasi \\
belajar dengan hasil belajar sosiologi. Metode penelitian yang digunakan dalam \\
penelitian ini adalah pendekatan kuantitatif korelasi dengan desain penelitian \\
cross sectional. Populasi dalam penelitian ini adalah siswa kelas XII SMA Batik \\
1 Surakarta. Sampel dalam penelitian ini sebanyak 132 responden yang dipilih \\
menggunakan teknik sample random sampling. Teknik pengumpulan data \\
dengan dokumentasi dan kuesioner. Analisis data menggunakan uji korelasi \\
product moment dan uji regresi ganda. \\
Berdasarkan Uji Regresi Ganda diperoleh model persamaan $Y=50,992+$ \\
$0,073 X_{1}+0,417 X_{2}$. Berdasarkan Uji Koefisien Korelasi didapatkan hasil: $(1)$ \\
tidak terdapat hubungan dan tidak signifikan antara kecemasan dengan hasil \\
belajar sosiologi ( $\left.r_{\text {hitung }}=>r_{\text {tabel }}=0,168<0,1697 ; p>0,05\right) ;(2)$ terdapat \\
hubungan positif dan signifikan antara motivasi belajar dengan hasil belajar \\
sosiologi ( $\left.r_{\text {hitung }}=>r_{\text {tabel }}=0,485>0,1697 ; p<0,05\right) ;(3)$ terdapat hubungan \\
antara kecemasan dan motivasi belajar dengan hasil belajar sosiologi $\left(R_{x y}>R_{\text {tabel }}\right.$ \\
$=0,509>0,1697 ;$ Sig $F$ Change $=0,000<0,05)$. \\
\hline This is an open access article under the Lisensi Creative Commons Atribusi- \\
\hline BerbagiSerupa 4.0 Internasional \\
(i) (O)
\end{tabular}
\end{abstract}

\section{PENDAHULUAN}

Di awal tahun 2020, dunia digemparkan dengan penemuan sebuah virus yang menyerang 
sistem pernapasan, virus ini dinamakan Novel Coronavirus 2019 (2019-nCoV). Virus ini pertama kali dikonfirmasi oleh pemerintah Tiongkok pada bulan Desember 2019. Setelah itu, Organisasi Kesehatan Dunia (WHO) mengumumkan lusinan kasus pneumonia yang terjadi di Wuhan, Tiongkok. Dikarenakan penyebaran virus ini sangatlah cepat, pada tanggal 11 Maret 2020, WHO mengumumkan coronavirus sebagai epidemi global atau yang kita kenal dengan pandemi Covid-19 (Fadli, 2020). Setelah ditetapkan sebagai pandemi, pemerintah di berbagai negara kemudian menerapkan lockdown atau isolasi total pada negaranya dengan menutup akses fasilitas publik dan transportasi. Masyarakat dihimbau untuk tetap berada di dalam rumah dan meminimalisir pertemuan dengan orang lain, harapannya agar virus tidak menyebar lebih luas.

Di Indonesia sendiri dalam rangka penanganan Covid-19 pada sektor pendidikan, Kementerian Pendidikan dan Kebudayaan (Kemendikbud) menerapkan kebijakan Learning From Home atau pembelajaran dari rumah. Pembelajaran yang dilakukan secara daring membuat kegiatan belajar mengajar dapat dijangkau dari berbagai waktu dan tempat, penggunaan media internet yang dianggap memudahkan para siswa untuk mencari informasi lebih luas serta kedekatan siswa generasi sekarang denagn teknologi yang memudahkan untuk beradaptasi dengan pembelajaran daring. Akan tetapi, terdapat beberapa kendala dalam penerapan pembelajaran daring seperti tidak meratanya jaringan internet di beberapa daerah, pengeluaran biaya untuk penggunaan kuota internet yang menjadi masalah bagi beberapa siswa yang mengalami kesulitan finansial, ketidaksiapan sekolah serta guru dalam memfasilitasi pembelajaran daring (Oktawirawan, 2020). Berdasarkan hasil survey yang dilakukan oleh Ikatan Psikolog Klinis (IPK) menunjukkan bahwa para siswa di Indonesia mengalami hambatan belajar, khususnya untuk anak dan remaja sebesar 27,2\%. Masalah psikologis yang paling banyak ditemukan pada semua kelompok usia yaitu keluhan stres umum sebesar 23,9\%, keluhan kecemasan 18,9\%, keluhan mood swing (perubahan suasana hati) 9,1\%, gangguan kecemasan 8,8\% dan keluhan psikosomatis 4,7\%. Berdasarkan periode layanan klinis psikolog, kelompok anak dan remaja mengalami kenaikan penerima layanan konseling pada awal pandemi lebih banyak daripadaa periode setelahnya (Halidi \& Fikri, 2020).

Dengan penerapan kebijakan pembelajaran daring ini membuat sebagian siswa merasa cemas dan tertekan. Cemas itu sendiri dianggap sebagai gangguan dalam perasaan yang ditandai dengan perasaan ketakutan atau kekhawatiran yang mendalam dan berkelanjutan, namun tidak mengalami gangguan dalam menilai realitas, kepribadian masih tetap utuh, perilaku dapat terganggu tetapi masih dalam batas normal (Hawari, 2011). Berbagai pemicu kecemasan siswa antara lain kurang memahami materi, deadline tugas, koneksi jaringan yang tidak stabil, kesulitan mengerjakan tugas, kesulitan perangkat penunjang pembelajaran daring, kesulitan kuota internet dan lain sebagainya (Prastiwi, 2020). Banyaknya tugas yang diberikan oleh guru membuat banyak siswa merasa stres (Chaterine, 2020). Selain itu, waktu pengerjaan yang diberikan oleh guru dinilai memberatkan karena dinilai terlalu singkat dan membuat para siswa merasa kebingungan dan kewalahan (Raharjo \& Sari, 2020).

Selain kecemasan, dampak dari penerapan pembelajaran daring adalah tingkat motivasi belajar siswa yang dinilai cukup rendah saat pembelajaran. Motivasi adalah sebuah dorongan yang muncul dari dalam diri seorang individu dan dapat menggerakkan individu tersebut untuk memenuhi harapannya (Dimyati \& Mudjiono, 2015). Beberapa faktor yang menyebabkan para siswa kehilangan motivasi untuk belajar adalah kurangnya dukungan dari keluarga khususnya orang tua, lingkungan pertemanan dan keterbatasan fasilitas. Seharusnya hal seperti ini menjadi tanggung jawab para siswa sebagai pelajar serta orang tua yang seharusnya memberikan dukungan kepada anaknya baik secara mental maupun psikis (Ghifari, 2021).

Motivasi belajar sangat berpengaruh dalam menentukan prestasi yang akan didapatkan oleh peserta didik. Dijelaskan dalam (Vivin, 2019) bahwa peserta didik yang memiliki motivasi belajar tinggi akan lebih tekun, memiliki semangat dan ambisi yang lebih tinggi untuk mencapai prestasi belajar. Sebaliknya, jika siswa tidak memiliki motivasi belajar maka tidak memiliki gairah untuk mengikuti kegiatan pembelajaran dan tidak memiliki perhatian terhadap pembelajaran. Berdasarkan penelitian yang dilakukan oleh Kirkland bahwa kecemasan dalam 
taraf sedang akan mendorong aktivitas belajar siswa, sedangkan kecemasan dengan taraf tinggi dapat mengganggu belajar siswa terlebih lagi pembelajaran yang dilaksanakan secara daring.

Berdasarkan informasi yang didapat pada SMA Batik 1 Surakarta, diperoleh bahwa sebagian siswa kelas XII dinilai masih kurang dalam beradaptasi dengan pembelajaran dalam jaringan (daring), sistem pembelajaran yang dinilai rumit dan membuat siswa kesulitan dalam memahami materi dapat menyebabkan siswa merasa cemas, tertekan dan merasa takut untuk bertanya saat pembelajaran berlangsung. Berkaitan dengan motivasi belajar, siswa terlihat masih kurang semangat dalam mengikuti pembelajaran sosiologi, kurang aktif dan cenderung pasif dikarenakan penggunaan metode belajar yang digunakan oleh guru bersifat monoton sehingga membuat siswa merasa bosan. Hal ini berpengaruh terhadap hasil belajar yang diperoleh siswa menjadi kurang maksimal. Penulisan artiken ini bertujuan untuk (1) mengetahui apakah terdapat pengaruh kecemasan terhadap hasil belajar sosiologi siswa kelas XII SMA Batik 1 Surakarta; (2) mengetahui apakah terdapat pengaruh motivais belajar rerhadap hasil belajar sosiologi siswa kelas XII SMA Batik 1 Surakarta; dan (3) mengetahui apakah terdapat pengaruh kecemasan dan motivasi belajar secara bersama-sama terhadap hasil belajar sosiologi siswa kelas XII SMA Batik 1 Surakarta.

\section{METODE PENELITIAN}

Metode penelitian yang digunakan dalam penelitian ini adalah pendekatan kuantitatif korelasi dengan desain penelitian cross sectional. Populasi dalam penelitian ini adalah siswa kelas XII SMA Batik 1 Surakarta dengan jumlah populasi sebanyak 405 siswa. Sampel pada penelitian ini sebanyak 132 responden yang dipilih menggunakan teknik sample random sampling. Pengambilan sampel secara acak didasarkan pada rumus slovin. Variabel yang digunakan dalam penelitian ini adalah Variabel Independen yaitu kecemasan dan motivasi belajar; Variabel Dependen yaitu hasil belajar sosiologi. Teknik pengumpulan data dengan dokumentasi dan kuesioner. Analisis data menggunakan analisis deskriptif dari setiap variabel. Untuk uji prasyarat analisis meliputi uji normalitas yang menggunakan uji Kolmogorov-Smirnov dan uji linieritas. Untuk uji hipotesis satu dan dua menggunakan uji korelasi product moment dan untuk uji hipotesis ketiga menggunakan uji regresi ganda. Data diolah dan dianalisa dengan menggunakan program SPSS 21.0.

\section{HASIL DAN PEMBAHASAN}

\subsection{Hasil Penelitian}

\section{Analisis Deskriptif}

Tabel 1 Analisis Deskriptif

\begin{tabular}{lccccc}
\hline \multicolumn{7}{c}{ Descriptive Statistic } \\
& $\mathrm{N}$ & Min & Max & Mean & $\begin{array}{c}\text { Std. } \\
\text { Deviation }\end{array}$ \\
\hline Hasil Belajar Sosiologi (Y) & 132 & 75 & 90 & 82 & 7,616 \\
\hline Kecemasan (X1) & 132 & 35 & 67 & 51 & 15,910 \\
\hline Motivasi Belajar (X2) & 132 & 57 & 74 & 65 & 8,257 \\
\hline Valid N & 132 & & & & \\
\hline
\end{tabular}

Berdasarkan tabel 1 diatas menunjukkan bahwa analisis data statistik variabel hasil belajar sosiologi memiliki rata-rata tertinggi yaitu 82, variabel kecemasan memiliki rata-rata 51, dan variabel motivasi belajar memiliki rata-rata 65 . Untuk standar deviasi variabel hasil belajar sosiologi memperoleh 7,616, variabel kecemasan memperoleh standar deviasi 15,910, dan variabel motivasi belajar sebesar 8,257. Untuk nilai maksimum dari variabel hasil belajar sosiologi diperoleh sebesar 90, variabel kecemasan sebesar 67, dan variabel motivasi belajar sebesar 74. Sedangkan nilai minimun dari hasil belajar sosiologi adalah sebesar 75, variabel kecemasan sebesar 35, dan variabel motivasi belajar 57. Hal ini menunjukkan bahwa hasil belajar sosiologi berada pada kategori sangat tinggi, kemudian variabel kecemasan berada pada kategori sangat tinggi, dan variabel motivasi belajar berada 
pada kategori sangat tinggi.

2. Uji Prasyarat Analisis

a. Uji Normalitas

Tabel 2 Hasil Uji Normalitas

\begin{tabular}{llrr}
\hline & & Kecemasan & \multicolumn{1}{c}{ Motivasi Belajar } \\
\hline $\mathrm{N}$ & & 132 & 132 \\
Normal Parameters & $\mathrm{a}, \mathrm{b}$ & 8,0705 &, 0000000 \\
& Mean &, 51338 & 6,65949459 \\
& Std. Deviation &, 081 &, 107 \\
& Absolute &, 081 &, 107 \\
Most Extreme Differences & Positive &,- 059 &,- 074 \\
& Negative &, 926 & 1,226 \\
Kolmogorov-Smirnov Z & &, 358 &, 099 \\
Asymp. Sig. (2-tailed) & & & \\
\hline
\end{tabular}

Dari tabel 2 menunjukkan hasil pengujian normalitas dengan menggunakan rumus Kolmogorov-Smirnov, pada variabel kecemasan diperoleh nilai signifikansi 0,358 dan nilai signifikansi pada variabel motivasi belajar adalah sebesar 0,99. Hal ini dapat disimpulkan bahwa data variabel kecemasan dan motivasi belajar berdistribusi normal.

b. Uji Linieritas

Tabel 3 Hasil Uji Linieritas

\begin{tabular}{ccc}
\hline Variabel & $\begin{array}{c}\text { Deviation } \\
\text { form Linierity }\end{array}$ & Keterangan \\
\hline Kecemasan & 0,491 & Linier \\
\hline $\begin{array}{c}\text { Motivasi } \\
\text { Belajar }\end{array}$ & 0,161 & Linier \\
\hline
\end{tabular}

Berdasarkan pada tabel 3, dapat diketahui bahwa nilai signifikansi Deviation from Linierity variabel kecemasan sebesar 0,491>0,05 dan variabel motivasi belajar memiliki nilai signifikansi sebesar $0,161>0,05$, sehingga dapat disimpulkan bahwa hubungan antara variabel bersifat linier.

3. Uji Hipotesis

a. Pengaruh antara Kecemasan (X1) terhadap Hasil Belajar Sosiologi (Y)

Tabel 4 Hasil Uji Korelasi Product-Moment X1 $\rightarrow$ Y

Correlations

\begin{tabular}{|c|c|c|c|}
\hline & & Kecemasan (X1) & $\begin{array}{l}\text { Hasil Belajar } \\
\text { Sosiologi }(Y)\end{array}$ \\
\hline \multirow{4}{*}{ Kecemasan (X1) } & Pearson Correlation & 1 & , 168 \\
\hline & Sig. (2-tailed) & & ,054 \\
\hline & $\mathrm{N}$ & 132 & 132 \\
\hline & Pearson Correlation & ,168 & 1 \\
\hline \multirow{2}{*}{$\begin{array}{l}\text { Hasil Belajar } \\
\text { Sosiologi (Y) }\end{array}$} & Sig. (2-tailed) & ,054 & \\
\hline & $\mathrm{N}$ & 132 & 132 \\
\hline
\end{tabular}

Berdasarkan tabel 4 ditemukan tidak ada pengaruh antara variabel kecemasan dengan hasil belajar sosiologi dengan nilai signifikansi sebesar 0,054 >0,05. Untuk nilai korelasi ( $\mathrm{r}_{\text {hitung }}$ ) antara kecemasan dengan hasil belajar sosiologi sebesar 0,168< $\mathrm{r}_{\text {tabel }}(0,1697)$. Nilai korelasi memiliki nilai negatif dan termasuk ke dalam kategori tidak memiliki hubungan. Sementara hasil pengujian signifikansi pada taraf 5\% diperoleh dari hasil perhitungan manual $t_{\text {hitung }}=1,943<\mathrm{t}_{\text {tabel }}=1,978$, maka dapat disimpulkan bahwa $\mathrm{H}_{\mathrm{O}}$ diterima dan $\mathrm{H}_{\mathrm{I}}$ ditolak. Hal ini berarti tidak ada pengaruh antara kecemasan terhadap hasil belajar sosiologi. 


\section{b. Pengaruh antara Motivasi Belajar (X2) terhadap Hasil Belajar Sosiologi (Y)}

Tabel 5 Hasil Uji Korelasi Product-Moment X2 $\rightarrow$ Y

Correlations

\begin{tabular}{|ll|r|r|}
\hline & & $\begin{array}{c}\text { Motivasi Belajar } \\
(\mathrm{X} 2)\end{array}$ & $\begin{array}{r}\text { Hasil Belajar } \\
\text { Sosiologi (Y) }\end{array}$ \\
\hline Motivasi Belajar (X2) & Pearson Correlation & 1 &, $485^{* *}$ \\
& Sig. (2-tailed) & 132 &, 000 \\
& $N$ &, $485^{* *}$ & 132 \\
Hasil Belajar Sosiologi & Pearson Correlation &, 000 & 1 \\
(Y) Sig. (2-tailed) & N & 132 & 132 \\
\hline \multirow{2*}{*}{. Correlation is significant at the 0.01 level (2-tailed). }
\end{tabular}

Berdasarkan tabel 5 ditemukan ada pengaruh variabel motivasi belajar dengan hasil belajar sosiologi dengan nilai signifikansi sebesar $0,000<0,05$. Untuk nilai korelasi ( $r_{\text {hitung }}$ ) antara kecemasan dengan hasil belajar sosiologi sebesar 0,485 $>r_{\text {tabel }}$ $(0,1697)$. Nilai korelasi memiliki nilai positif yang berarti hubungan kedua variabel searah dengan korelasi sedang. Sementara hasil pengujian signifikansi pada taraf $5 \%$ diperoleh dari hasil perhitungan manual nilai $t_{\text {hitung }}=9,079>\mathrm{t}_{\text {tabel }}=1,978$, sehingga $\mathrm{H}_{\mathrm{O}}$ ditolak dan $\mathrm{H}_{\mathrm{I}}$ diterima, diperoleh kesimpulan bahwa variabel motivasi belajar memiliki hubungan positif dan signifikan dengan variabel hasil belajar sosiologi siswa kelas XII IPS SMA Batik 1 Surakarta.

c. Pengaruh antara Kecemasan (X1) dan Motivasi Belajar (X2) secara bersama-sama terhadap Hasil Belajar Sosiologi (Y)

Tabel 6 Hasil Uji Regresi Ganda Coefficients $^{\mathrm{a}}$

\begin{tabular}{|c|c|c|c|c|c|c|}
\hline \multirow{2}{*}{\multicolumn{2}{|c|}{ Model }} & \multicolumn{2}{|c|}{ Unstandardized Coefficients } & \multirow{2}{*}{$\begin{array}{c}\begin{array}{c}\text { Standardized } \\
\text { Coefficients }\end{array} \\
\text { Beta }\end{array}$} & \multirow[t]{2}{*}{$t$} & \multirow[t]{2}{*}{ Sig. } \\
\hline & & B & Std. Error & & & \\
\hline \multirow{3}{*}{1} & (Constant) & 50,992 & 4,718 & & 10,807 &, 000 \\
\hline & Kecemasan (X1) & 073 & ,036 & 154 & 2,030 & ,044 \\
\hline & Motivasi Belajar (X2) & ,417 & ,066 & ,481 & 6,342 &, 000 \\
\hline
\end{tabular}

a. Dependent Variable: Hasil Belajar Sosiologi $(Y)$

Berdasarkan tabel 6 menunjukan bahwa nilai konstanta sebesar 50,992 berarti jika nilai Kecemasan (X1) dan Motivasi Belajar (X2) sebesar 0, maka besarnya Hasil Belajar Sosiologi bernilai 50,992. Hal ini menggambarkan ketika hasil belajar sosiologi belum dipengaruhi oleh variabel independen. Nilai koefisien korelasi regresi Kecemasan (X1) sebesar 0,073. Memiliki arti jika setiap penambahan kecemasan sebesar 1, maka nilai Hasil Belajar Sosiologi (Y) akan menambah sebesar 0,073. Nilai koefisien korelasi regresi Motivasi Belajar (X2) sebesar 0,417. Memiliki arti jika setiap penambahan motivasi belajar sebesar 1, maka nilai Hasil Belajar Sosiologi (Y) akan menambah sebesar 0,417.

Tabel 7 Hasil Koefisien Determinasi Model Summary

\begin{tabular}{|c|c|c|c|c|c|c|c|c|c|}
\hline \multirow[t]{2}{*}{ Model } & \multirow[t]{2}{*}{$\mathrm{R}$} & \multirow{2}{*}{$\begin{array}{c}\mathrm{R} \\
\text { Square }\end{array}$} & \multirow{2}{*}{$\begin{array}{c}\text { Adjusted } \\
\text { R } \\
\text { Square }\end{array}$} & \multirow{2}{*}{$\begin{array}{l}\text { Std. Error } \\
\text { of the } \\
\text { Estimate }\end{array}$} & \multicolumn{5}{|c|}{ Change Statistics } \\
\hline & & & & & $\begin{array}{c}\text { R Square } \\
\text { Change }\end{array}$ & F Change & $\mathrm{df1}$ & $\mathrm{df2}$ & $\begin{array}{c}\text { Sig. F } \\
\text { Change }\end{array}$ \\
\hline 1 & $\begin{array}{r}, 509 \\
a\end{array}$ & ,259 & ,248 & 6,60624 & ,259 & 22,561 & 2 & 129 &, 000 \\
\hline
\end{tabular}

a. Predictors: (Constant), Motivasi Belajar (X2), Kecemasan (X1)

Berdasarkan tabel 7 mengidentifikasi ditemukannya pengaruh signifikan variabel indipenden dan variabel dependen dengan nilai signifikansi (Sig F Change) $0,000<0,05$. Untuk nilai koefisien korelasi ganda sebesar 0,509 >0,1697 $\left(R_{x y}>R_{\text {tabel }}\right)$ sehingga $\mathrm{H}_{\mathrm{O}}$ ditolak dan $\mathrm{H}_{\mathrm{I}}$ diterima, jadi kesimpulannya bahwa variabel kecemasan dan motivasi belajar secara bersama-sama mempengaruhi dengan variabel hasil belajar 
sosiologi. Kemudian diperoleh koefisien determinasi yang dapat dilihat pada $R$ Square sebesar 0,259 yang mengandung pengertian bahwa variabel bebas yaitu kecemasan (X1) dan motivasi belajar (X2) memiliki pengaruh terhadap terhadap variabel terikat yaitu hasil belajar sosiologi (Y) sebesar 25,9\% dan sisanya sebesar 74,1\% dipengaruhi oleh variabel lain.

Tabel 8 Hasil Uji F Regresi Ganda ANOVA $^{\mathrm{a}}$

\begin{tabular}{|rl|r|r|r|r|r|}
\hline Model & & Sum of Squares & Df & Mean Square & F & Sig. \\
\hline \multirow{2}{*}{1} & Regression & 1969,197 & 2 & 984,598 & 22,561 &, $000^{\mathrm{b}}$ \\
& Residual & 5629,864 & 129 & 43,642 & & \\
& Total & 7599,061 & 131 & & & \\
\hline
\end{tabular}

a. Dependent Variable: Hasil Belajar Sosiologi (Y)

b. Predictors: (Constant), Motivasi Belajar (X2), Kecemasan (X1)

Berdasarkan tabel 8, diketahui bahwa nilai uji F sebesar 22,561 > 3,06 ( $F_{\text {hitung }}>$ $\left.F_{\text {tabel }}\right)$ dengan tingkat signifikansi sebesar $0,000<0,05$, maka dapat disimpulkan bahwa terdapat pengaruh variabel kecemasan (X1) dan motivasi belajar (X2) terhadap variabel hasil belajar sosiologi (Y).

\subsection{PEMBAHASAN}

Berdasarkan hasil penelitian yang telah dilakukan pada siswa kelas XII SMA Batik 1 Surakarta, menunjukkan bahwa tidak terdapat pengaruh negatif dan signifikan antara kecemasan (X1) terhadap hasil belajar sosiologi (Y). Kecemasan adalah sebuah perasaan takut pada sesuatu yang tidak jelas dan berhubungan dengan perasaan yang tidak menentu dan membuat tidak berdaya. Hal ini senada dengan yang diungkapkan oleh (Hawari, 2011) mengatakan bahwa kecemasan merupakan suatu gangguan dalam perasaan yang biasanya ditandai dengan perasaan ketakutan atau kekhawatiran yang mendalam dan berjangka. Menurut (Halmuniati, Hasiati, Wui, \& Awad, 2020) terdapat salah satu jenis kecemasan yaitu kecemasan yang membantu, tingkat kecemasan (biasanya relatif rendah akan meningkatkan performa, sehingga sedikit mengalami kecemasan akan mendorong siswa untuk memperoleh hasil belajar yang baik. Hasil penelitian ini sejalan dengan (Supardi \& Leonard, 2010) bahwa kecemasan siswa tidak memberikan pengaruh bagi peningkatan hasil belajar siswa. Dengan kata lain, semakin tinggi kecemasan siswa maka semakin rendah hasil belajar siswa dan sebaliknya, semakin rendah hasil belajar siswa maka semakin tinggi hasil belajar siswa. Penelitian ini berhasil menemukan bahwa tidak terdapat pengaruh kecemasan terhadap hasil belajar sosiologi, sehingga siswa yang mampu mengontrol tingkat kecemasannya maka akan berhasil dalam proses pembelajaran.

Berdasarkan hasil penelitian yang telah dilakukan menunjukkan bahwa terdapat pengaruh yang positif dan signifikan antara motivasi belajar (X2) terhadap hasil belajar sosiologi (Y). Hasil penelitian ini sejalan dengan (Nur'aini, Patarru, \& Palobo, 2021) bahwa terdapat pengaruh secara signifikan antara motivasi belajar dan hasil belajar. Hal ini juga sesuai dengan pendapat (Uno, 2011) yang menjelaskan bahwa motivasi merupakan dorongan yang ada pada diri individu dalam berusaha untuk melakukan perubahan sikap menjadi lebih baik untuk memenuhi kebutuhan orang tersebut. Siswa yang memiliki motivasi belajar yang tinggi akan lebih tekun, bersemangat dan memiliki ambisi yang lebih tinggi dalam mencapai hasil belajar yang lebih baik, dibandingan dengan siswa yang kurang atau tidak memiliki motivasi belajar. Bagi siswa yang tidak memiliki motivasi belajar akan terlihat kurang atau tidak bergairah, tidak berpartisipasi aktif dalam belajar maupun mengikuti pembelajaran di kelas. kondisi siswa yang kurang memiliki motivasi belajar sudah tentu tidak mampu menghasilkan prestasi yang memuaskan.

Berdasarkan hasil penelitian yang telah dilakukan pada siswa kelas XII SMA Batik 1 Surakarta menunjukkan bahwa terdapat pengaruh yang positif dan signifikan antara kecemasan (X1) dan motivasi belajar (X2) secara bersama-sama terhadap hasil belajar sosiologi (Y). Pada penelitian ini, variabel paling dominan adalah variabel motivasi belajar 
dengan nilai Beta sebesar 0,481. Hal ini disebabkan karena motivasi belajar sebagai dorongan yang berhubungan dengan pencapaian keunggulan yang terdapat di dalam diri siswa sehingga ia berusaha maksimal dalam semua aktivitas pembelajaran. Selain itu didapatkan hasil koefisien determinasi yang disimbolkan dengan $R$ Square sebesar 0,259. Hal ini berarti variabel independen yaitu kecemasan dan motivasi belajar memiliki perngaruh terhadap variabel dependen yaitu motivasi belajar sosiologi sebesar $25,9 \%$ dan sisanya sebesar $74,1 \%$ dipengaruhi oleh variabel lain. Hasil belajar sosiologi telah diteliti secara luas, sehingga variabel dalam penelitian ini hanya memiliki pengaruh sebesar $25,9 \%$. Penelitian ini sependapat dengan penelitian (Widodo, Laelasari, Sari, Nur, \& Putrianti, 2017) yang membuktikan bahwa terdapat pengaruh antara kecemasan dan motivasi belajar terhadap hasil belajar siswa secara simultan.

\section{KESIMPULAN}

Berdasarkan data yang diperoleh dari hasil analisis yang telah dilakukan maka dapat ditarik kesimpulan sebagai berikut

1. Tidak terdapat hubungan dan signifikan antara Kecemasan dan Hasil Belajar Sosiologi pada siswa kelas XII IPS SMA Batik 1 Surakarta. Hal tersebut terbukti berdasarkan hasil uji korelasi product moment (tabel 4) yang mengindikasikan hubungan kedua variabel tidak signifikan dengan nilai signifikansi sebesar $0,054>0,05$. Untuk nilai korelasi $\left(r_{\text {hitung }}\right)$ antara kecemasan dengan hasil belajar sosiologi sebesar $0,168<r_{\text {tabel }}(0,1697)$. Siswa yang memiliki kecemasan yang rendah akan memiliki hasil belajar yang tinggi.

2. Terdapat hubungan positif dan signifikan antara Motivasi Belajar dengan Hasil Belajar Sosiologi pada siswa kelas XII IPS SMA Batik 1 Surakarta. Hal tersebut terbukti berdasarkan hasil uji korelasi product moment (tabel 5) yang mengindikasikan hubungan kedua variabel signifikan dengan nilai signifikansi sebesar $0,000<0,05$. Untuk nilai korelasi $\left(r_{\text {hitung }}\right)$ antara kecemasan dengan hasil belajar sosiologi sebesar 0,485 $>r_{\text {tabel }}$ $(0,1697)$. Siswa yang memiliki motivasi belajar tinggi akan terlihat lebih tekun, berambisi tinggi sehingga mencapai hasil belajar yang tinggi.

3. Terdapat hubungan signifikan antara Kecemasan dan Motivasi Belajar secara bersama-sama dengan Hasil Belajar Sosiologi pada siswa kelas XII IPS SMA Batik 1 Surakarta. Hal tersebut terbukti dengan uji regresi berganda (tabel 7) yang mengindikasikan signifikansi $0,000<0,05$ berarti terdapat hubungan signifikan variabel kecemasan dan motivasi belajar secara bersama-sama terhadap variabel hasil belajar sosiologi. Untuk nilai koefisien regresi ganda sebesar 0,509 $>0,1697\left(R_{x y}>R_{\text {tabel }}\right)$ dengan model persamaan garis regresinya yaitu $Y=50,992+0,073 X_{1}+0,417 X_{2}$.

\section{SARAN}

Dari hasil yang telah didapatkan maka disarankan bagi sekolah diharapkan dapat menciptakan lingkungan belajar yang nyaman demi kelancaran proses belajar pembelajaran secara daring selama pandemi. Selain itu, bagi guru hendaknya guru tidak menambah beban pada siswa sehingga kecemasan siswa dalam pembelajaran sosiologi terutama pada pembelajaran daring dimasa pandemi covid-19 saat ini tidak menjadi tinggi. Selain itu guru diharapkan mampu memberikan motivasi kepada para siswa untuk belajar agar hasil belajar sosiologi menjadi optimal.

\section{DAFTAR PUSTAKA}

Chaterine, R. N. (2020). Siswa Belajar dari Rumah, KPAI: Anak-anak Stres Dikasih Banyak Tugas. News.Detik.Com. Retrieved from https://news.detik.com/berita/d4944071/siswa-belajar-dari-rumah-kpai-anak-anak-stres-dikasih-banyak-tugas

Dimyati, \& Mudjiono. (2015). Belajar dan Pembelajaran. Jakarta: Rineka Cipta.

Fadli, R. (2020). Timeline Virus Corona, Dari Desember 2019 Hingga Kini. Retrieved March 10, 2021, from halodoc.com website: https://www.halodoc.com/artikel/timeline-viruscorona-dari-desember-2019-hingga-kini 
Ghifari, I. (2021). Rendahnya Semangat Belajar Siswa Di Tengah Pandemi. Kompasiana.Com. Retrieved https://www.kompasiana.com/muhammadirfanghifari8593/604e46d68ede4875bd0212b 3/rendahnya-semangat-belajar-siswa-ditengah-pandemi

Halidi, R., \& Fikri, L. K. (2020). Survei: 23 Persen Remaja Alami Stres Karena Belajar Daring. Suara.Com. Retrieved from https://www.suara.com/health/2020/10/14/225135/survei23-persen-remaja-alami-stres-karena-belajar-daring

Halmuniati, Hasiati, Wui, L., \& Awad, F. B. (2020). Pengaruh Motivasi Belajar dan Tingkat Kecemasan Terhadap Prestasi Belajar IPA Siswa MTsN 2 Konawe Selatan. 1, 70-76. https://doi.org/10.31332/kd.v1i2.2028

Hawari, D. (2011). Manajemen Stres Cemas dan Depresi. Jakarta: Fakultas Kedokteran Universitas Indonesia.

Nur'aini, K. D., Patarru, H., \& Palobo, M. (2021). Pengaruh Motivasi Belajar dan Kecemasan Matematika Terhadap Kesadaran Metakognisi dengan Hasil Belajar Matematika Siswa. Jurnal Pendidikan Matematika, https://doi.org/https://doi.org/10.35724/mjme.v3i2.3539

Oktawirawan, D. H. (2020). Faktor Pemicu Kecemasan Siswa dalam Melakukan Pembelajaran Daring di Masa Pandemi Covid-19. Jurnal Ilmiah, 20.

Prastiwi, T. W. (2020). Kecemasan Siswa saat PJJ, Perlu Perhatian Menyeluruh. Radarsemarang.Id. Retrieved from https://radarsemarang.jawapos.com/rubrik/untukmuguruku/2020/10/25/kecemasan-siswa-saat-pjj-perlu-perhatian-menyeluruh/

Raharjo, D. B., \& Sari, R. R. N. (2020). Belajar Online di Tengah Corona, Ada Siswa Mengeluh Tensi Darah Naik. Suara.Com. Retrieved from https://www.suara.com/news/2020/03/19/205940

Supardi, \& Leonard. (2010). Pengaruh Konsep Diri, Sikap Siswa Pada Matematika, dan Kecemasan Siswa Terhadap Hasil Belajar Matematika. Jurnal Ilmiah Pendidikan.

Uno, H. B. (2011). Teori Motivasi \& Pengukurannya. Jakarta: Bumi Aksara.

Vivin, V. (2019). Kecemasan dan motivasi belajar. Persona:Jurnal Psikologi Indonesia, 8(2), 240-257. https://doi.org/10.30996/persona.v8i2.2276

Widodo, S. A., Laelasari, L., Sari, R. M., Nur, I. R. D., \& Putrianti, F. G. (2017). Analisis Faktor Tingkat Kecemasan, Motivasi dan Prestasi Belajar Mahasiswa. Jurnal Pendidikan, 1. https://doi.org/https://doi.org/10.30738/tc.v1i1.1581 